https://jurnal.univpgri-

palembang.ac.id/index.php/luminous

\title{
PENGEMBANGAN ALAT PERAGA FISIKA CRANE MAGNETIC POKOK BAHASAN MEDAN MAGNET PADA SELENOIDA
}

\author{
Virgiani Pangestika Fajrin ${ }^{1 *}$, Yayat Ruhiat ${ }^{2}$, Dina Rahmi Darman ${ }^{3}$ \\ ${ }^{123}$ Program Studi Pendidikan Fisika, Fakultas Keguruan dan IImu Pendidikaan, Universitas Sultan Ageng Tirtayasa \\ Kota Serang, Indonesia \\ Email Penulis : virgianipangestika@gmail.com
}

Received: 1401 2021. Accepted: 0902 2021. Published: 15022021

\begin{abstract}
Abstrak
Penelitian ini bertujuan untuk mengembangkan dan mengetahui kelayakan alat peraga fisika crane magnetic pokok bahasan medan magnet pada selenoida. Alat peraga fisika crane magnetic yang dikembangkan memiliki kompenen utama, yaitu solenoida dan power supply dc. Metode penelitian yang digunakan pada penelitian ini adalah metode penelitian dan pengembangan (Research and Development) dengan model pengembangan 4D yang di modifikasi peneliti menjadi tiga tahap, yaitu define, design, dan development. Sementara untuk mengetahui kelayakan alat peraga fisika crane magnetic dilakukan uji validasi oleh ahli dan ujicoba terbatas pada peserta didik kelas XI SMAN 6 Kota Serang. Hasil validasi pada alat peraga fisika crane magnetic pokok bahasan medan magnet oleh ahli media sebesar $81,5 \%$, ahli materi sebesar $91,65 \%$, dan hasil ujicoba terbatas sebesar $96,7 \%$. Seluruh ahli alat peraga fisika crane magnetic menyatakan bahwa produk alat peraga fisika crane magnetic sangat layak digunakan sebagai media pembelajaran dan mendapatkan respon positif dari peserta didik.
\end{abstract}

(C) 2021 Pendidikan Fisika FKIP UPGRI Palembang

Kata Kunci: Penelitian dan pengembangan, alat peraga fisika, crane magnetic, fisika, dan medan magnet

\section{PENDAHULUAN}

Medan magnet merupakan materi yang penting dikuasai oleh siswa karena materi ini menjadi dasar untuk beberapa materi lain seperti induksi Faraday, teknologi digital, dan gelombang elektromagnetik. Materi medan magnet dapat menjadi bekal pengetahuan bagi siswa karena banyak penerapan medan magnet di kehidupan sehari-hari seperti kipas angin, mesin cuci, alat ukur listrik, dan masih banyak lagi (Wullan et al., 2017). Menurut Purwanto, et al. (2016) materi medan magnet memiliki karakteristik khusus, yaitu materinya bersifat abstrak karena medan magnet tidak dapat ditangkap oleh indera penglihatan, bersifat matematis karena selalu ada perumusan matematis dalam setiap fenomena konsep medan magnet, bersifat aplikatif karena konsep ini digunakan pada produk teknologi dalam kehidupan sehari-hari.

Sejalan dengan berkembangnya kurikulum pendidikan, dimana kurikulum 2013 dikembangkan dengan penyempurnaan pola pembelajaran pasif menjadi pembelajaran aktif (Kementrian Pendidikan dan Kebudayaan, 2013). Melihat kenyataan di atas guru dituntut untuk melakukan 
perbaikan pada proses pembelajaran (Darman, et al., 2017). Oleh karena itu, diperlukannya alat peraga dalam pembelajaran fisika, khususnya materi yang bersifat abstrak.

Alat peraga merupakan media pembelajaran yang dapat membangkitkan motivasi siswa dalam mempelajari fisika. Alat peraga juga dapat memberi rangsangan kepada siswa untuk lebih aktif sehingga proses pembelajaran menjadi lebih interaktif dan tidak monoton. Menurut Syaiful Bahri Djamarah dan Aswan Zain (2010) alat peraga sangat efektif dan efesien digunakan dalam proses pembelajaran fisika, khususnya dalam materi medan magnet yang erat kaitannya dengan listrik dan magnet yang sifatnya abstrak.

Berdasarkan hasil observasi di SMAN 6 kota Serang, hasil belajar siswa pada pelajaran fisika materi medan magnet di kelas XII masih tergolong rendah. Hasil belajar siswa yang rendah pada materi medan magnet karena pembelajaran masih konvensional dan pasif. Fakta lain di lapangan, yaitu berdasarkan hasil wawancara dengan guru fisika di SMAN 6 Kota Serang bahwa beberapa alat praktikum yang digunakan dalam pembelajaran tidak dapat digunakan dalam proses belajar mengajar khususnya pada alat dan bahan praktikum materi medan magnet. Hal tersebut di sebabkan karena kurang terawat dan minimnya alat dan bahan yang tersedia pada laboratorium sekolah (Rosdiana, Suherman, \& Darman, 2019). Oleh karena itu, guru jarang menggunakan alat praktikum/alat peraga dalam kegiatan pembelajaran fisika di sekolah. Sehingga pemahaman pada materi medan magnet menjadi kurang maksimal jika tidak didampingi dengan alat praktikum/alat peraga.

Berdasarkan hasil penelitian sebelumnya, pengembangan media pembelajaran alternative telah dilakukan untuk menganalisa besaran medan magnet yang diakibatkan oleh kawat loop melingkar berarus (Anugrah, Serevina, \& Nasbey, 2015). Pada penelitian yang dilakukan oleh Afriyanto (2015) pengembangan media pembelajaran alat peraga pada materi hukum biot savart dengan memanfaatkan induksi magnetik yang dihasilkan oleh kumparan. Namun, pengembangan alat peraga medan magnet masih terdapat kekurangan diantaranya alat peraga medan magnet belum dapat mengukur nilai dari medan magnet $(B)$ dan gaya magnet $(F)$ secara akurat, serta belum dilengkapi dengan buku petunjuk (manual book) penggunaan alat untuk memperpanjang usia kerja alat (Wullan et al., 2017).

Berdasarkan pemaparan di atas, maka dibutuhkan pengembangan alat peraga terbaru yang dapat digunakan oleh guru untuk melatih dan menjelaskan konsep medan magnet secara interaktif. Oleh karena itu, pengembangan media pembelajaran yang berupa alat peraga fisika crane magnetic pokok bahasan medan magnet pada selenoida di kelas XII SMA perlu dilakukan.

\section{METODE}

Metode pada penelitian ini, yaitu metode penelitian dan pengembangan (research and development). Penelitian dan pengembangan alat peraga fisika crane magnetic menggunakan model 4D oleh Thiagarajan (1974). Model pengembangan 4D terdiri dari empat tahap yang di modifikasi menjadi tiga tahap, yaitu pendefinisian (define), desain (design), dan pengembangan (develop). Tahap pendistribusian (disseminate) tidak dilakukan karena tujuan dalam penelitian ini adalah mengembangkan media pembelajaran yang baik. Adapun penjelasan dari setiap tahapan adalah sebagai berikut:

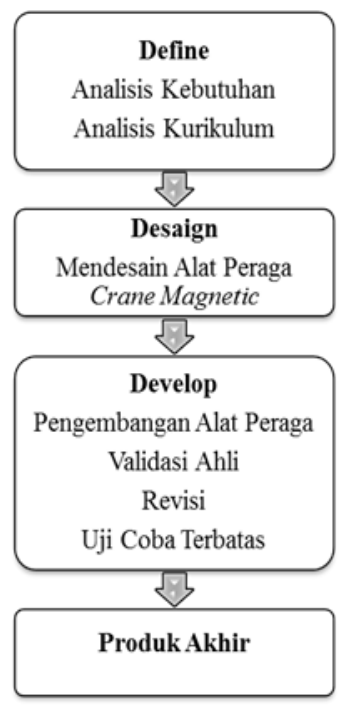


Gambar 1. Modifikasi Model Pengembangan 4D

Tahap difine, dilakukan observasi dan wawancara untuk menganalisis kebutuhankebutuhan di dalam proses pembelajaran fisika dari berbagai informasi, mengkaji materi serta menganalisis kurikulum yang akan digunakan sebagai acuan dalam pembuatan alat peraga. Hal ini dimaksudkan data yang diambil dari observasi digunakan sebagai referensi pembuatan alat peraga serta penentuan komponen yang akan dipakai dalam penelitian nanti. Wawancara dilakukan untuk mengidentifikasi masalah yang berkaitan dengan permasalahan alat peraga yang digunakan dalam proses pembelajaran.

Tahap design merupakan langkah awal untuk menentukan bentuk alat yang akan dibuat. Rancangan atau design alat peraga yang dikembangkan menggunakan alat dan bahan yang mudah didapatkan. Setelah alat dan bahan didapatkan, langkah selanjutnya adalah merangkai alat dan bahan menjadi alat peraga fisika crane magnetic dengan dilengkapi buku petunjuk penggunaan alat peraga fisika crane magnetic dan lembar kerja siswa (LKS).

Tahap develop bertujuan untuk menghasilkan produk akhir alat peraga fisika crane magnetic setelah dilakukan validasi dan revisi berdasarkan saran dan masukan para ahli serta ujicoba terbatas. Para ahli melakukan validasi dengan cara mengisi angket penilaian yang telah disediakan.

Data yang dihasilkan merupakan kumpulan dari ahli media dan materi, serta respon peserta didik. Adapun sampel yang digunakan dalam penelitian ini adalah tiga orang ahli media dan materi, serta 10 orang peserta didik SMAN 6 Kota Serang.

Instrument pada penelitian ini menggunakan penilaian skala Guttman.

Tabel 1. Kategori skala Guttman

\begin{tabular}{cc}
\hline Skor & Keterangan \\
\hline 1 & Ya \\
\hline 0 & Tidak \\
\hline
\end{tabular}

Data uji angket validasi ahli media, ahli materi dan ujicoba terbatas alat peraga fisika crane magnetic dapat dianalisis dengan menghitung persentase rata-rata tiap komponen dengan menggunakan rumus sebagai berikut:

$$
P=\frac{\sum X}{X i X} 100 \%
$$

Keterangan:

$P \quad=$ Presentase skor (dibulatkan)

$\Sigma X=$ Jumlah skor jawaban tiap responden dalam satu item

$X i=$ Jumlah skor ideal dalam satu item

Tabel 2. Kriteria Kelayakan Alat Peraga

\begin{tabular}{cc}
\hline $\begin{array}{c}\text { Tingkat Pencapaian } \\
(\%)\end{array}$ & Kualifikasi \\
\hline $81 \%-100 \%$ & Sangat Layak \\
\hline $61 \%-80 \%$ & Layak \\
\hline $41 \%-60 \%$ & Cukup Layak \\
\hline $21 \%-40 \%$ & Kurang Layak \\
\hline$<20 \%$ & $\begin{array}{c}\text { Sangat Kurang } \\
\text { Layak }\end{array}$ \\
\hline
\end{tabular}

\section{HASIL DAN PEMBAHASAN}

Produk yang dihasilkan berupa alat peraga fisika crane magnetic. Crane magnetic merupakan suatu perangkat alat yang dapat mengangkat benda-benda magnetic. Alat peraga fisika crane magnetic menggunakan konsep medan magnetik di sekitar kawat selenoida berarus listrik, dimana komponen utama dalam alat ini adalah solenoida dan power supply dc. Alat peraga fisika crane magnetic ini dirancang untuk dapat memvariasikan arus listrik dan jumlah lilitan untuk menghasilkan kuat medan magnet dan hubungannya dengan gaya magnet yang ditunjukkan dengan besarnya gaya tarik magnet terhadap benda dalam bentuk gaya berat.

Alat peraga fisika crane magnetic yang dikembangkan memiliki bagian-bagian, yaitu: akrilik, power supply dan kabel, ampermeter, pipa paralon, katrol, kumparan, inti besi, logam, plastik massa, dynamo, tali, kontra jack, saklar, tombol on/off, dan neraca digital. 
Setelah alat peraga fisika crane magnetic dikembangkan, tahap selanjutnya yaitu validasi oleh ahli media dan ahli materi. Data hasil validasi oleh 3 orang ahli media dan ahli materi dapat dilihat pada tabel sebagai berikut.
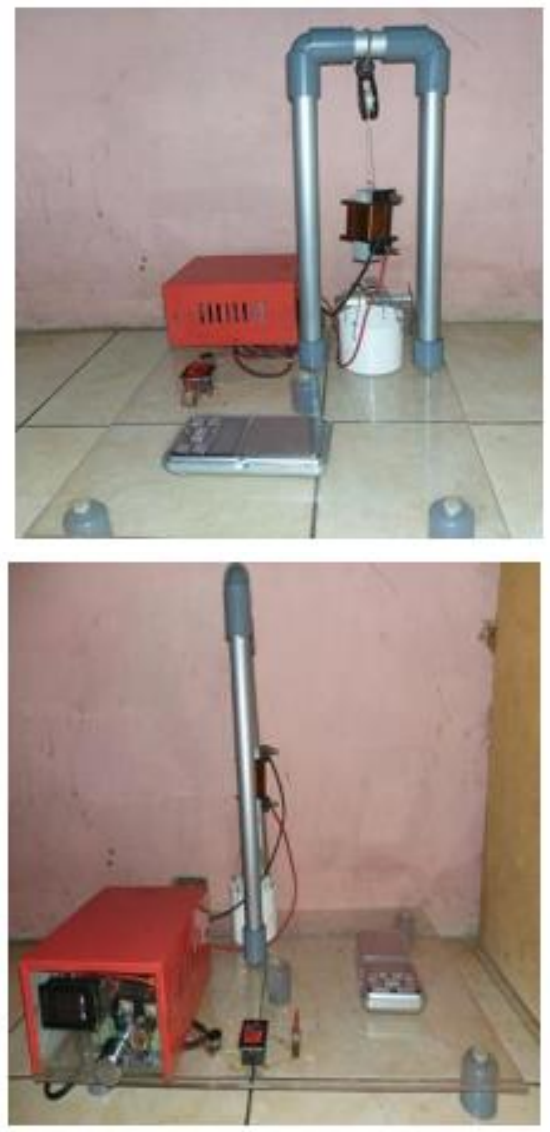

GAMBAR 2. TAMPAK SAMPING DAN TAMPAK DEPAN ALAT PERAGA FISIKA CRANE MAGNETIC

Tabel 3. Hasil Validasi Ahli Media

\begin{tabular}{llccc}
\hline No & \multicolumn{1}{c}{$\begin{array}{c}\text { Aspek } \\
\text { Kelayakan } \\
\text { Media }\end{array}$} & $\begin{array}{c}\text { Jumlah } \\
\text { Skor } \\
\text { Validator }\end{array}$ & $\begin{array}{c}\text { Skor } \\
\text { Ideal }\end{array}$ & $\begin{array}{c}\text { Persentase } \\
(\%)\end{array}$ \\
\hline 1 & $\begin{array}{l}\text { Ketahanan } \\
\text { Alat }\end{array}$ & 5 & 9 & $55,6 \%$ \\
\hline 2 & $\begin{array}{l}\text { Keakuratan } \\
\text { Alat }\end{array}$ & 9 & 9 & $100 \%$ \\
\hline 3 & Efesiensi Alat & 5 & 6 & $83,3 \%$ \\
\hline 4 & Estetika & 6 & 6 & $100 \%$ \\
\hline 5 & $\begin{array}{l}\text { Keamanan } \\
\text { bagi Peserta } \\
\text { Didik }\end{array}$ & 4 & 6 & $67,7 \%$ \\
\hline 6 & $\begin{array}{l}\text { Kotak Alat } \\
\text { Peraga }\end{array}$ & 5 & 6 & $83,3 \%$ \\
\hline
\end{tabular}

Rata-Rata Skor Keseluruhan

$81,5 \%$

Berdasarkan tabel diketahui bahwa aspek ketahanan alat mendapatkan penilaian sebesar $55,6 \%$, sehingga aspek ketahan alat peraga fisika crane magnetic dikategorikan cukup layak. Aspek keakuratan alat mendapatkan penilaian sebesar $100 \%$, sehingga aspek keakuratan alat dikategorikan sangat layak. Penilaian aspek efesiensi alat mendapatkan nilai sebesar $83,3 \%$, sehingga aspek efesiensi alat dikategorikan sangat layak. Aspek keamanan bagi peserta didik mendapatkan penilaian 100\%, sehingga aspek keamanan bagi peserta didik dikategorikan sangat layak. Penilaian aspek estetika mendapatkan nilai sebesar 66,7\%, sehingga aspek estetika dikategorikan layak. Aspek kotak alat peraga mendapatkan penilaian sebesar $83,3 \%$, sehingga aspek kotak alat peraga dikategorikan sangat layak. Seluruh aspek kelayakan media diperoleh hasil penilaian rata-rata oleh ahli media, yaitu: $81,5 \%$ pada alat peraga fisika crane magnetic yang dikategorikan sangat layak untuk digunakan sebagai alat peraga fisika.

Tabel 4. Hasil Validasi Ahli Materi

\begin{tabular}{llccc}
\hline No & $\begin{array}{c}\text { Aspek } \\
\text { Kelayakan } \\
\text { Materi }\end{array}$ & $\begin{array}{c}\text { Jumlah } \\
\text { Skor }\end{array}$ & $\begin{array}{c}\text { Skor } \\
\text { Ideal }\end{array}$ & $\begin{array}{c}\text { Persentase } \\
(\%)\end{array}$ \\
\hline 1 & $\begin{array}{l}\text { Keterkaitan } \\
\text { dengan } \\
\text { Bahan Ajar }\end{array}$ & 9 & 9 & $100 \%$ \\
\hline 2 & $\begin{array}{l}\text { Nilai } \\
\text { Pendidikan }\end{array}$ & 5 & 6 & $83,3 \%$ \\
\hline \multicolumn{3}{l}{ Rata-Rata Skor Keseluruhan } & $91,65 \%$ \\
\hline
\end{tabular}

Bedasarkan tabel diketahui bahwa aspek keterkaitan dengan bahan ajar mendapatkan penilaian sebesar $100 \%$, sehingga aspek keterkaitan dengan bahan ajar dikategorikan sangat layak. Aspek nilai pendidikan mendapatkan penilaian sebesar $83,3 \%$, sehingga aspek nilai pendidikan dikategorikan sangat layak. Seluruh aspek kelayakan materi diperoleh hasil penilaian rata-rata oleh ahli materi, yaitu: 91,65\% yang dikategorikan sangat layak. 
Setelah dilakukan validitas oleh ahli media dan ahli materi, tahap selanjutnya dilakukan revisi sesuai saran dan masukan dari ahli media dan ahli materi. Setelah itu di uji cobakan kepada peserta didik kelas XI SMAN 6 Kota Serang. Berikut data hasil ujicoba terbatas dapat dilihat pada tabel.

Tabel 5. Hasil Ujicoba Terbatas

\begin{tabular}{lllll}
\hline No & $\begin{array}{l}\text { Aspek } \\
\text { Respon } \\
\text { Siswa }\end{array}$ & $\begin{array}{l}\text { Jumlah } \\
\text { Skor } \\
\text { Responden }\end{array}$ & $\begin{array}{l}\text { Skor } \\
\text { Maks }\end{array}$ & $\begin{array}{l}\text { Persentase } \\
(\%)\end{array}$ \\
\hline 1 & $\begin{array}{l}\text { Keterkaitan } \\
\text { dengan } \\
\text { Bahan Ajar }\end{array}$ & 40 & 40 & $100 \%$ \\
& Estetika & 27 & 30 & $90 \%$ \\
\hline 2 & Efesiensi & 30 & 30 & $100 \%$ \\
\hline & Alat & & \\
\hline & Rata-Rata Skor Keseluruhan & $96,7 \%$
\end{tabular}

Berdasarkan tabel diketahui bahwa aspek keterkaitan dengan bahan ajar mendapatkan nilai sebesar $100 \%$, sehingga aspek ini di kategorikan sangat layak. Aspek estetika mendapatkan penilaian sebesar $90 \%$ sehingga aspek ini mendapat kategori sangat layak, dan aspek efesiensi alat mendapatkan penilaian $100 \%$, sehingga aspek ini di kategorikan sangat layak. Hasil ujicoba terbatas disimpulkan bahwa alat peraga fisika crane magnetic yang dikembangkan memenuhi kategori sangat layak digunakan sebagai media pembelajaran dengan nilai ratarata persentase skor seluruh aspek, yaitu sebesar $96,7 \%$.

Alat peraga fisika crane magnetic yang dikembangkan dapat memberikan stimulus pada peserta didik untuk lebih aktif, sehingga alat peraga sebagai salah satu media pembelajaran yang efektif dan efesien dalam proses pembelajran fisika khususnya materi medan magnet yang berakaitan erat dengan listrik dan magnet dan bersifat abstrak. Hal ini sesuai dengan peryataan Afriyanto (2015) yang menyatakan bahwa proses belajar dengan menggunakan alat peraga yang ditujukan pada peserta didik lebih memudahkan dalam menjelaskan dan dipahami oleh peserta didik. Alat peraga fisika crane magnetic dikembangkan berdasarkan pengembangan sebelumnya oleh Erwan Afriyanto dengan mengambangkan jumlah lilitan dan pengaruh arus untuk menghasilkann kuat medan magnet dan hubungannya dengan gaya magnet yang ditujukan dengan besarnya gaya Tarik magnet terhadap benda dalam bentuk gaya berat.

Alat peraga fisika crane magnetic juga dapat menumbuhkan hasrat dan keinginan belajar peserta didik, serta membuat proses belajar peserta didik menjadi lebih menarik. Pernyataan di atas sesuai dengan hasil penelitian peneliti dari angket respon peserta didik sebesar $96,7 \%$. Selain itu, pernyataan diatas didukung oleh penelitian Cahyani (2013) yang mengatakan bahwa penggunaan alat peraga sebagai media pembelajaran dalam proses belajar dapat membangkitkan keingintahuan, motivasi dan memberikan stimulus pada peserta didik.

Alat peraga fisika crane magnetic yang dikembangkan oleh peneliti dapat menjelaskan materi medan magnet pada seleoida. Selain itu, ketahan alat peraga fisika crane magnetic memiliki tingkatan baik dan dilengkapi buku petunjuk penggunaan alat peraga guna memperpanjang hidup alat peraga. Keunggulan alat peraga fisika crane magnetic, aman digunakan oleh peserta didik karena arus yang dihasilkan adalah arus DC. Alat peraga fisika crane magnetic dapat mempermudah siswa dalam memahami faktor-faktor yang mempengaruhi kuat medan magnet dan hubungannya dengan gaya magnet yang ditunjukan dengan besarnya gaya tarik magnet terhadap benda dalam bentuk gaya berat, hal ini dapat dilakukan dengan mengatur besarnya voltase pada power supply dan jumlah lilitan. Keterbatasan dalam penelitian dan pengembangan ini, yaitu alat peraga fisika crane magnetic tidak dapat digunakan di sekolah yang tidak memiliki aliran listrik seperti sekolah di daerah 3T, minimnya jumlah alat peraga yang dikembangkan sehingga membuat peserta didik harus bergantian dalam menggunakan alat peraga tersebut, dan alat peraga fisika crane magnetic 
belum sampai dalam tahap penyebaran (disseminate) karena tahap ini belum dilakukan dalam penelitian mengingat peneliti memodifikasi model pengembangan 4D menjadi tiga tahap.

\section{KESIMPULAN DAN SARAN}

Berdasarkan hasil penelitian dan pengembangan alat peraga fisika crane magnetic yang dikembangkan telah dilakukan uji validitas dan memiliki kriteria sangat layak digunakan di dalam pembelajaran fisika dengan hasil validasi media sebesar $81,5 \%$, dan ahli materi sebesar $91,65 \%$. Selain itu, hasil ujicoba terbatas setelah menggunakan alat peraga fisika crane magnetic mendapatkan nilai sebesar $96,7 \%$ dengan kriteria sangat baik. Hal ini dapat disimpulkan bahwa alat peraga fisika crane magnetic sangat layak digunakan didalam proses pembelajaran.

\section{DAFTAR PUSTAKA}

Afriyanto, E. (2015). Pengembangan Media Pembelajaran Alat Peraga pada Materi Hukum Biot Savart di SMA Negeri 1 Prambanan Klaten. Jurnal Riset Dan Kajian Pendidikan Fisika, 2(1), 20. https://doi.org/10.12928/jkpf.v2i1.3131

Anugrah, M. I., Serevina, V., \& Nasbey, H. (2015). Pengembangan Alat Praktikum Medan Magnet Sebagai Media Pembelajaran Fisika SMA. Prosiding Seminar Nasional Fisika (EJournal) SNF2015, IV, 125-130. Retrieved from

http://journal.unj.ac.id/unj/index.php/prosiding snf/article/view/4994

Cahyani, A. Y. (2013). Pengembangan Modul Ipa Terpadu Tema Dampak Asap Kendaraan Bermotor Terhadap Kesehatan. USEJ Unnes Science Education Journal, 2(2), 302310. https://doi.org/10.15294/usej.v2i2.2040

Darman, D. R., Wibowo, F. C., Putra, A., \& Hasra, A. (2017). Pengembangan Buku Kerja Fisika
Berbasis Kontekstual Pada Konsep Suhu Dan Kalor. Gravity: Jurnal IImiah Penelitian Dan Pembelajaran Fisika, 3(2), 120-133. https://doi.org/10.30870/gravity.v3i2.2596

Kementrian Pendidikan dan Kebudayaan. (2013). Peraturan Menteri Pendidikan Pendidikan Dan Kebudayaan Republik Indonesia Nomor 69 Tahun 2013 Tentang Kerangka Dasar Dan Struktur Kurikulum Sekolah Menengah Atas/Madrasah Aliyah. Jakarta: Kementrian Pendidikan Dan Kebudayaan.

Purwanto, A., Hendri, M., \& Susanti, N. (2016). Studi Perbandingan Hasil Belajar Siswa Menggunakan Media PhET Simulations dengan Alat Peraga pada Pokok Bahsan Listrik Magnet di Kelas IX SMPN Kabupaten Tebo. Jurnal EdulFisika, 1(1), 22-27.

Rosdiana, D., Suherman, A., \& Darman, R. (2019). Pengembangan Media Pembelajaran Virtual Physics Laboratory (ViPhyLab) Dalam Praktikum Hukum Kirchoff. Journal of Natural Science, $2(2), \quad 11$. https://doi.org//10.24014/jnsi.v2i2.7906

Syaiful Bahri Djamarah dan Aswan Zain. (2010). Strategi Belajar Mengajar (Edisi Revisi). Jakarta: Rineka Cipta.

Wullan, N. S. R. I. (2017). Pengaruh Alat Peraga Medan Magnet ( APMM ) Terhadap Hasil Belajar Siswa Pada Konsep. Unpublished

Thesis. Tangerang Selatan: UIN Syarif Hidayatullah Jakarta 